\title{
Recovery of Polluted Urban Stormwater Containing Heavy Metals: Laboratory-Based Experiments with Arlita and Filtralite
}

\author{
Concepcion Pla ${ }^{1, *(\mathbb{D}}$, David Benavente ${ }^{2} \mathbb{(}$, Javier Valdes-Abellan ${ }^{1}$ and Antonio Jodar-Abellan ${ }^{3}$ \\ 1 Department of Civil Engineering, University of Alicante, San Vicente del Raspeig, 03690 Alicante, Spain; \\ javier.valdes@ua.es \\ 2 Department of Earth and Environmental Sciences, University of Alicante, San Vicente del Raspeig, \\ 03690 Alicante, Spain; david.benavente@ua.es \\ 3 University Institute of Water and Environmental Sciences, University of Alicante, San Vicente del Raspeig, \\ 03690 Alicante, Spain; antonio.jodar@ua.es \\ * Correspondence: c.pla@ua.es
}

Citation: Pla, C.; Benavente, D.;

Valdes-Abellan, J.; Jodar-Abellan, A.

Recovery of Polluted Urban

Stormwater Containing Heavy

Metals: Laboratory-Based

Experiments with Arlita and Filtralite.

Water 2021, 13, 780. https://doi.org/

10.3390/w13060780

Academic Editor: Francesco De Paola

Received: 2 February 2021

Accepted: 11 March 2021

Published: 13 March 2021

Publisher's Note: MDPI stays neutral with regard to jurisdictional claims in published maps and institutional affiliations.

Copyright: (C) 2021 by the authors. Licensee MDPI, Basel, Switzerland. This article is an open access article distributed under the terms and conditions of the Creative Commons Attribution (CC BY) license (https:// creativecommons.org/licenses/by/ $4.0 /)$.

\begin{abstract}
Heavy-metal sources in urban environments include automobile exhaust, fuel combustion, tires, road asphalt, weathering of building materials, and/or industrial activities. The presence of heavy metals in urban stormwaters constitutes a potential risk for water resources and aquatic life. Results from the present study demonstrated the effectiveness of two different lightweight aggregates (LWAs), Arlita and Filtralite, to remove heavy metals ( $\mathrm{Ni}, \mathrm{Cu}, \mathrm{Zn}, \mathrm{Cd}$, and $\mathrm{Pb}$ ) present in aqueous solutions. These materials were selected because they previously showed great results for water treatment and because of their physicochemical properties. The removal efficiency of the studied materials was evaluated with batch tests containing solutions contaminated with heavy metals (with individual and multiple contaminants) at different concentrations mixed with the LWA particles. Filtralite showed a better performance in heavy metal removal than Arlita: higher adsorption capacity for all metals, and lower release of metals from contaminated particles into washing water. The average removal capacities in tests developed with solutions containing individual contaminants for Arlita and Filtralite were $76 \%$ and $90 \%$, respectively, although the values varied across the different contaminants. Metal elimination by LWAs was more effective with individual contaminated solutions than with multielemental ones. The analysis of the adsorption curves, the mineral precipitation on the LWA surface, and the geochemical modeling confirmed that two different mechanisms are responsible for the heavy-metal removal. First, the rough surface of the LWA presents sorbing surface sites of the forming minerals, resulting in the ion-exchange reactions of metal ions. Second, the LWA-water interaction causes an increase in solution $\mathrm{pH}$, which triggers the precipitation and coprecipitation of the metals in the form of oxide and hydroxides. The study confirms that the use of Arlita and especially Filtralite present promising potential to remove heavy metals from urban stormwaters.
\end{abstract}

Keywords: metal precipitation; ion exchange; $\mathrm{pH}$; lightweight aggregates; urban drainage systems

\section{Introduction}

Currently, urban runoff results in a considerable nonstop source of pollutants, causing severe global environmental problems [1-4]. This pronounced increment of pollutants is mainly related to growing populations in urban areas [5] and, thus, to the expansion of impervious areas [6,7] caused by unsuitable and unsustainable urbanization. This produces adverse effects such as an increase in flood volumes and maximum water discharges. In addition, the raise in the frequency of extreme precipitation events $[1,8,9]$, according to climate change predictions [10], will accentuate those effects. The expansion of urban areas affects not only the amount of water but also its quality and distribution during the hydrologic circulation [11]. Infiltration may decrease by up to 15-40\% [12], causing a clear modification of the natural water cycle. Stormwtater managers have become essential for 
urban development due to the increase in urban flooding [13,14]. Particularly, in arid and semiarid Mediterranean areas, the presence of convective storms with short duration and high intensity [15] accentuates the urbanization effect and directly affects the exacerbation of pollutant wash-off, causing a deterioration in water quality [16].

In urban impervious areas, non-infiltrated water from precipitation leads to large volumes of runoff that must be collected and treated because of the presence of waterborne contaminants $[17,18]$. Regarding stormwater quality treatment, the early stage of precipitation events deserves special attention, as the majority of the pollutants are washed off within this period [19]. Different kinds of pollutants constitute stormwater contamination: organic matter, suspended solids, phosphorus, nitrogen, hydrocarbons, and/or heavy metals [16,19-23]. Among them, heavy metals are characterized by their toxicity, long-term accumulation, and persistence $[3,24,25]$. The main sources of heavy metals are automobile exhaust, fuel combustion, tires, road asphalt, weathering of building materials, and industrial activities [26,27]. They exist in the form of precipitates (associated with suspended particulates) or are dissolved in aqueous solutions. The latter form constitutes a potential risk since contaminants cannot be degraded to harmless molecules, contrary to organic compounds [28]. They have high mobility and can be transported as complexed compounds, allowing them to reach surface water and groundwater resources, affecting aquatic life and human water supply [29-31]. The mobility and toxic potential of heavy metals depend strongly on the adsorption and desorption processes, controlled by the flow regime, $\mathrm{pH}$, redox conditions, temperature, heavy-metal concentration, and existence of particulates $[29,32]$. Those previous studies have demonstrated that the efficiency of heavy-metal removal is worse when heavy metals are dissolved in water rather than as particulate-bound metals [29,32].

Heavy-metal extraction from urban stormwaters can be afforded by different technologies including chemical precipitation, chemical coagulation, ion exchange, electrochemical methods, adsorption processes, membrane technologies, and filtration [33-38]. Recent trends in stormwater management highly encourage the employment of best management practice techniques aiming to achieve both flood protection and the improvement of water quality via a reduction in pollutants [39]. The implementation of sustainable urban drainage systems (SUDS), low impact development (LID) designs, or green infrastructures (GI) allows the quantitative and qualitative control of stormwater runoff [40]. Among these, SUDS minimize flood risk caused by runoff stormwater and enhance water quality through harvesting, infiltrating, slowing, storing, conveying, and treating water volumes on site, while simultaneously magnifying the green spaces in the urban city planning [41].

In these systems, it is critical to guarantee a high infiltration rate to reduce the water runoff rate over the land surface. Therefore, the employed filter materials are mainly aggregates, geotextiles, and engineered soils [41] that guarantee an adequate infiltration rate but do not show such good characteristics when dealing with pollutant removal. Recent research has been devoted to the search for different filter materials suitable to work as part of the filter systems in SUDS. For instance, Soleimanifar et al. [42] evaluated the capacity of wood mulches coated with water treatment residuals for the alleviation of heavy metals and phosphorus in urban stormwater. Charlesworth et al. [43] used coarse grades of compost in leaching columns to remediate contamination as potential materials to be used in SUDS. Davis et al. [26] demonstrated the effectiveness of bioretention boxes, composed of sandy loam soil, mulch, and juniper plants, for removing heavy metals from water. In addition, the employment of permeable pavements for sustainable stormwater management has also demonstrated successful results. Permeable pavements with high $\mathrm{CaCO}_{3}$ concentrations seemed to offer the best results to reduce heavy-metal pollution because they forced the precipitation of these pollutants and their adsorption [21].

Aggregates composed of calcite, zeolite, sand, etc. have demonstrated excellent results in removing heavy metals from contaminated water [27], but they lack the high hydraulic conductivity required to include them in the drainage system network. Among filter materials, the employment of lightweight aggregates (LWAs) shows interesting 
benefits. LWAs are defined as a wide range of construction materials initially used in civil engineering and architecture to reduce the concrete density and to improve the thermoinsulation properties of buildings. Additionally, they have shown excellent hydraulic conductivity and removal capacity of different water-borne pollutants, and there is scientific evidence of lightweight expanded clay aggregates providing outstanding results when treating standard urban wastewater, mainly related to their sorption capacity [44]. The LWA industry produces considerable amounts of aggregates which are regarded as wastes from the point of view of traditional applications [45], and their use to remove heavy-metal contents from urban stormwater would suppose an environmentally friendly solution to remove pollutants from water. Among the whole family of LWAs, those made from lightweight expanded clay constitute the mainstream in civil engineering. However, as far as we know, the scientific literature has not fully addressed the problem of heavy-metal removal from urban stormwater using this family of LWAs, characterized by a very high hydraulic conductivity.

The main objective of this paper was to determine the effectiveness of two different lightweight expanded clay aggregates as potential materials to remove heavy metals dissolved in urban runoff stormwaters. For this purpose, the physicochemical properties of the selected LWA were firstly determined. We established the removal capacity of the materials according to batch tests with aqueous solutions of individual contaminants $(\mathrm{Ni}, \mathrm{Cu}, \mathrm{Zn}$, $\mathrm{Cd}$, and $\mathrm{Pb}$ ) and multielemental solutions containing all of them. The selection of the target heavy metals included the metals whose concentration is limited by European and Spanish regulations in soils and wastewater sludges (RD 506/2013 [46]; RD 865/2010 [47]; RD 1310/1990 [48]; UE 2015/2099 [49]) and which have been scientifically reported in urban environments from transport and urban activities [50,51]. We also studied the reversibility of the decontamination process through washing stages of the contaminated material, trying to simulate the different phases of urban storms. Both aqueous samples and solid particles were analyzed in this study. Lastly, we developed a numerical simulation with geochemical software to assist us in the identification of the processes taking place in the experiments.

\section{Materials and Methods}

\subsection{Characterization of Filter Materials}

Two different lightweight aggregates obtained from expanded clay (the commercial names of the materials in the present study were Arlita Leca and Filtralite) were tested to determine their behavior as filter materials to remove urban stormwater runoff pollution. The materials were washed with deionized water and air-dried before any use. The characterization of the mineralogical composition of filter materials was determined by $\mathrm{X}$-ray diffraction (XRD) using a Philips PW diffractometer with $\mathrm{Cu} \mathrm{K} \alpha$ radiation. XRD data were collected and interpreted using the XPowder software package [52], which allows a quantitative analysis of the identified phases. The calculation of the global amorphous phase considers that amorphous absorption contributes to the full-profile background and represents an approximate percentage of amorphous phases in the sample. The presence of amorphous oxides was evaluated combining Raman spectroscopy (Jasco NRS-5100 dispersive Raman system) and the amorphous fraction obtained with XRD. The chemical composition of the major elements was performed using X-ray fluorescence (XRF, Philips Magix Pro device).

Field-emission scanning electron microscopy (FESEM, ZEISS Merlin VP Compact device) was employed to determine the microstructure of Arlita and Filtralite. EDX (energydispersive X-ray) was also applied to chemically characterize the elements associated with the FESEM images.

The specific surface area (SSA) was determined using the nitrogen adsorption technique through the Brunauer-Emmett-Teller (BET) method [53]. 


\subsection{Aqueous Contaminated Solutions}

All the tests used synthetic contaminated water which roughly simulated real urban runoff stormwater. To produce this polluted water, five heavy metals $\mathrm{Zn}, \mathrm{Cu}, \mathrm{Pb}, \mathrm{Ni}$, and Cd) were introduced into the solution. Typical ranges of concentration for heavy metals in urban stormwater can vary from $10^{-3}$ to $49 \mathrm{mg} \cdot \mathrm{L}^{-1}(\mathrm{Ni}), 6 \times 10^{-5}$ to $1.4 \mathrm{mg} \cdot \mathrm{L}^{-1}(\mathrm{Cu})$, $7 \times 10^{-4}$ to $22 \mathrm{mg} \cdot \mathrm{L}^{-1}(\mathrm{Zn}), 5 \times 10^{-5}$ to $13.7 \mathrm{mg} \cdot \mathrm{L}^{-1}(\mathrm{Cd})$, and $6 \times 10^{-4}$ to $26 \mathrm{mg} \cdot \mathrm{L}^{-1}$ $(\mathrm{Pb})[7,27,54-56]$. The different concentrations of each contaminant were prepared using different commercial chemical compounds: $\mathrm{ZnSO}_{4}, \mathrm{CuSO}_{4}$ (PanReac AppliChem ITW Reagents), $\mathrm{PbCl}_{2}$ (EMD Millipore Corporation), $\mathrm{NiCl}_{2}$ (Sigma Aldrich), and $\mathrm{CdSO}_{4}$ (Alfa Aesar). The $\mathrm{pH}$ measurements were conducted following the UNE-ISO10390:2012 [57] standard using a Crison $25+\mathrm{pH}$ meter $( \pm 0.01$ accuracy).

\subsection{Batch Experiments}

Metal removal efficiency of Arlita and Filtralite was evaluated with batch experiments. Contaminated aqueous solutions $(100 \mathrm{~mL})$ were combined with the solid particles of each LWA $(10 \mathrm{~g})$ to perform these experiments. The concentration for these solutions ranged from 50 to $500 \mathrm{mg} \cdot \mathrm{L}^{-1}(\mathrm{Ni}), 2.5$ to $25 \mathrm{mg} \cdot \mathrm{L}^{-1}(\mathrm{Cu}), 25$ to $250 \mathrm{mg} \cdot \mathrm{L}^{-1}(\mathrm{Zn}), 15$ to $150 \mathrm{mg} \cdot \mathrm{L}^{-1}(\mathrm{Cd})$, and 5 to $50 \mathrm{mg} \cdot \mathrm{L}^{-1}(\mathrm{~Pb})$. In this study, the lowest concentration employed for the batch tests roughly coincided with the upper value of the abovementioned concentration ranges. Thus, the employed concentrations were higher than expected for real stormwater $[7,27,54-56]$. Aqueous solutions containing the different metals individually were inserted into a glass bottle (height $=10 \mathrm{~cm}$ and diameter $=4.5 \mathrm{~cm}$ ) with the LWA particles at room temperature. The mixture underwent a stirring process for $24 \mathrm{~h}$. Aqueous samples from the studied solution were analyzed before and after the experiments in order to establish differences in concentration between the original and final solutions. Analysis consisted of $\mathrm{pH}$ measurements and inductively coupled plasma mass spectrometry (ICPMS) analysis (Agilent 7700x). The presence of precipitated compounds of metals on the solid adsorbents was analyzed under FESEM. For this purpose, we selected dried Arlita and Filtralite particles after the batch tests developed with the maximum concentration.

After batch tests with individual contaminants, batch tests with multielemental solutions containing all the contaminants were also developed employing the same conditions to investigate the potential interactions or synergistic effects among the five elements. Lastly, with the unique objective of analyzing the impact of the studied materials on the $\mathrm{pH}$, a final batch test was developed with deionized water.

In the batch experiments, the amount of metal removed by the solid particles per unit of mass (i.e., the adsorbate capacity; $\mathrm{S}, \mathrm{mg}^{-\mathrm{g}^{-1}}$ ) was calculated with Equation (1), using the initial $\left(\mathrm{Ci}, \mathrm{mg} \cdot \mathrm{L}^{-1}\right)$ and equilibrium concentration $\left(\mathrm{Ce}, \mathrm{mg} \cdot \mathrm{L}^{-1}\right)$, the mass $(\mathrm{g})$ of the solid particles $(\mathrm{m})$, and the volume of the contaminated solution $(\mathrm{V}, \mathrm{mL})$.

$$
\mathrm{S}=\frac{(\mathrm{C} i-\mathrm{Ce}) \mathrm{V}}{\mathrm{m}} .
$$

The reversibility of the process was also studied and, consequently, the capacity of LWAs for fixing the contaminants. After finishing the batch test with both individual and multiple contaminant solutions, the contaminated LWAs coming from the second highest concentrated solution (Ni: $350 \mathrm{mg} \cdot \mathrm{L}^{-1} ; \mathrm{Cu}: 17.5 \mathrm{mg} \cdot \mathrm{L}^{-1} ; \mathrm{Zn}: 175 \mathrm{mg} \cdot \mathrm{L}^{-1} ; \mathrm{Cd}: 105 \mathrm{mg} \cdot \mathrm{L}^{-1}$; $\mathrm{Pb}: 35 \mathrm{mg} \cdot \mathrm{L}^{-1}$ ) were oven-dried and tested again for both Arlita and Filtralite. Then, $5 \mathrm{~g}$ of each material was inserted into a bottle and stirred with $50 \mathrm{~mL}$ of deionized water for a period of $24 \mathrm{~h}$. Amounts of solid and water were selected to keep the concentrations in the determination range of the equipment employed.

\subsection{Heavy-Metal Concentration in the Synthetic Water under Different $p H$ Values}

We evaluated the influence of $\mathrm{pH}$ on the metal concentration in the stormwater using one of the contaminated aqueous solution in a range of $\mathrm{pH}$ values increasing from 4 to 12 (and later decreasing from 12 to 4 ). The initial solution was composed of $100 \mathrm{mg} \cdot \mathrm{L}^{-1}$ 
$\mathrm{Ni}, 5 \mathrm{mg} \cdot \mathrm{L}^{-1} \mathrm{Cu}, 50 \mathrm{mg} \cdot \mathrm{L}^{-1} \mathrm{Zn}, 30 \mathrm{mg} \cdot \mathrm{L}^{-1} \mathrm{Cd}$, and $10 \mathrm{mg} \cdot \mathrm{L}^{-1} \mathrm{~Pb}$. Then, a solution of $\mathrm{NaOH}(0.06 \mathrm{M})$ was gradually added to a multielemental contaminated solution (100 mL). Changes in $\mathrm{pH}$ as a consequence of the $\mathrm{NaOH}$ addition were registered, and consecutive samples were collected to observe changes in metal concentration after the ICP-MS analysis. Once the $\mathrm{NaOH}$ experiment finished, a second phase began gradually adding $\mathrm{HCl}(0.5 \mathrm{M})$ to reduce the $\mathrm{pH}$. Samples were also collected and analyzed following the same procedure as in the first part of the test.

\subsection{Geochemical Modeling}

The precipitation process was simulated with the PHREEQC code using 3.4.0 version [58] in order to assist us in the determination of the role of precipitation processes in the reduction in heavy metals from the stormwater. PHREEQC was used to calculate the saturation index, SI, which is defined as follows (Equation (2)):

$$
\mathrm{SI}=\log \left(\frac{\mathrm{IAP}}{\mathrm{K}}\right),
$$

where IAP is the ion activity product, and $\mathrm{K}$ is the equilibrium constant. The saturation index determines whether the water is saturated $(\mathrm{SI}=0)$, undersaturated $(\mathrm{SI}<0)$, or supersaturated (SI $>0$ ) with respect to the given mineral or phase. The variation in $\mathrm{pH}$ of the initial contaminated solutions due to the interaction with LWA was simulated by adding different concentrations of $\mathrm{NaOH}$ at different steps using the methodology described in Benavente et al. [59], in isothermal conditions, through the REACTION keyword in PHREEQC. Specific ion interaction theory was applied to estimate single-ion activity coefficients in electrolyte solutions (ionic strength values lower than $0.05 \mathrm{~mol} \cdot \mathrm{kgw}^{-1}$ ) using the Mintq.v4 thermodynamic database.

\section{Results and Discussion}

\subsection{Filter Material Characterization}

The mineralogical compositions of both filter materials reflected the presence of common clay minerals (Table 1). Calcite was not present in Arlita and was scarce in Filtralite. The chemical composition of the major elements of both solids was similar and in concordance with XRD analysis (Table 2).

Table 1. Semiquantitative mineralogical composition of Arlita and Filtralite.

\begin{tabular}{ccccccc}
\hline$\%$ & $\begin{array}{c}\text { Quartz } \\
\mathbf{S i O}_{\mathbf{2}}\end{array}$ & $\begin{array}{c}\text { Anorthite } \\
(\mathbf{C a}, \mathbf{N a}) \mathbf{A l}_{\mathbf{2}} \mathbf{S i}_{\mathbf{2}} \mathbf{O}_{\mathbf{8}}\end{array}$ & $\begin{array}{c}\text { K-Feldspart } \\
(\mathbf{K}, \mathbf{N a})(\mathbf{S i}, \mathbf{A l})_{\mathbf{4}} \mathbf{O}_{\mathbf{8}}\end{array}$ & $\begin{array}{c}\text { Wadsleyite } \\
(\mathbf{M g}, \mathbf{F e})_{\mathbf{2}} \mathbf{S i O}_{\mathbf{4}}\end{array}$ & $\begin{array}{c}\text { Calcite } \\
\mathbf{C a C O}_{\mathbf{3}}\end{array}$ & $\begin{array}{c}\text { Amorphous } \\
\mathbf{P h a s e s}\end{array}$ \\
\hline Arlita & 31.5 & 18.7 & 11.2 & 28.9 & - & 9.7 \\
Filtralite & 20.4 & 22.8 & 18.7 & 18.7 & 5.9 & 13.5 \\
\hline
\end{tabular}

Table 2. Chemical composition of Arlita and Filtralite.

\begin{tabular}{|c|c|c|c|c|c|c|c|c|c|c|c|}
\hline$\%$ & $\mathrm{Na}_{2} \mathrm{O}$ & $\mathrm{MgO}$ & $\mathrm{Al}_{2} \mathrm{O}_{3}$ & $\mathrm{SiO}_{2}$ & $\mathrm{P}_{2} \mathrm{O}_{5}$ & $\mathrm{SO}_{3}$ & $\mathrm{~K}_{2} \mathrm{O}$ & $\mathrm{CaO}$ & $\mathrm{TiO}_{2}$ & $\mathrm{MnO}$ & $\mathrm{Fe}_{2} \mathrm{O}_{3}$ \\
\hline Arlita & 0.29 & 4.25 & 18.86 & 60.13 & 0.17 & 0.16 & 3.92 & 3.39 & 0.92 & 0.09 & 7.82 \\
\hline Filtralite & 1.94 & 4.78 & 16.21 & 59.12 & 0.23 & 0.17 & 4.09 & 4.51 & 0.79 & 0.12 & 8.04 \\
\hline
\end{tabular}

Raman spectra presented bands related to iron oxides, similar to hematite ones (circa 296,400 , and $1330 \mathrm{~cm}^{-1}$ [60]). These results match with the iron concentration obtained with XRF (Table 2) and support the presence of amorphous iron oxides shown in the XRD pattern (Table 1).

FESEM images (Figure 1) show the large intraparticle porosity of Arlita and Filtralite and also reveal a rough surface of the filter solid materials. The specific surface areas (SSAs) for Arlita and Filtralite were $0.44 \mathrm{~m}^{2} \cdot \mathrm{g}^{-1}$ and $1.60 \mathrm{~m}^{2} \cdot \mathrm{g}^{-1}$, respectively. These values are in accordance with other clayed lightweight aggregates [45] and correspond to 
macroporous materials. SSAs for these lightweight aggregates were much more lower than the SSAs of typical adsorbents such as clays $\left(22.0 \mathrm{~m}^{2} \cdot \mathrm{g}^{-1}\right.$ [61]), zeolites $\left(15.8 \mathrm{~m}^{2} \cdot \mathrm{g}^{-1}\right.$ [62]), nanofibrous adsorbents $\left(58.6 \mathrm{~m}^{2} \cdot \mathrm{g}^{-1}[62]\right)$, and activated carbon $\left(849 \mathrm{~m}^{2} \cdot \mathrm{g}^{-1}\right.$ [63]), which limits, comparatively, their superficial reactivity for sorption reactions.

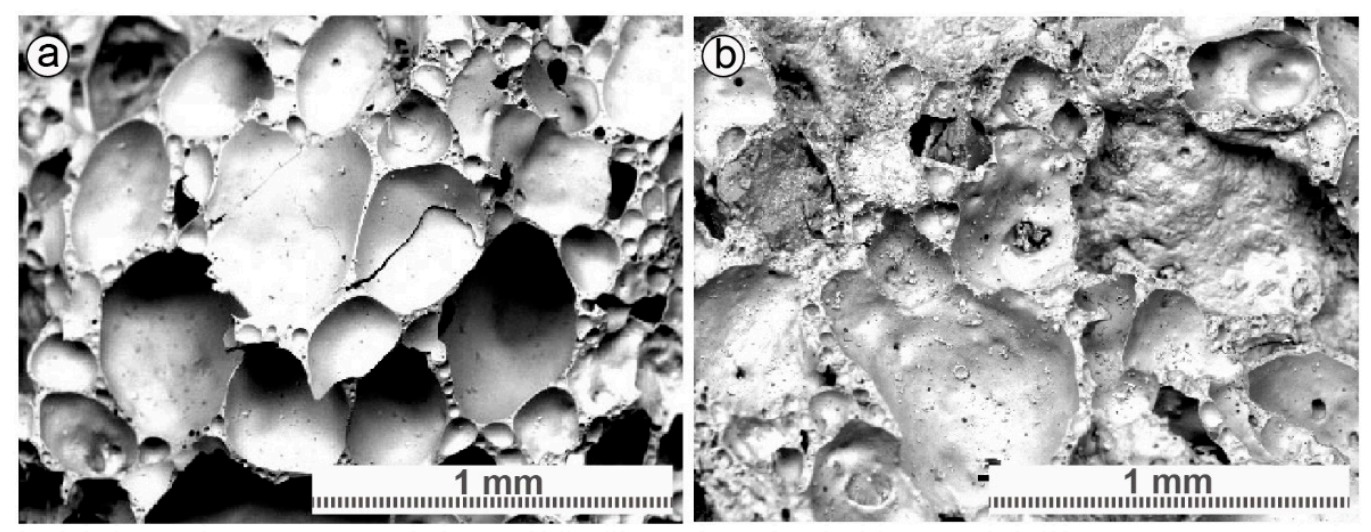

Figure 1. Morphological features of the particle surface for Arlita (a) and Filtralite (b).

\subsection{Batch Experiments}

Figure 2 shows the results obtained from the batch experiments. The general trend for all the contaminants shows that Filtralite always presented a higher removal capacity than Arlita, although this behavior changed for the different contaminants. For instance, Filtralite stabilized at a maximum equilibrium concentration of $234.34 \mathrm{mg} \cdot \mathrm{L}^{-1}$ and $100.00 \mathrm{mg} \cdot \mathrm{L}^{-1}$ for $\mathrm{Ni}$ (Figure 2a) and Cd (Figure 2d), respectively, and presented a retention capacity of $6.29 \mathrm{mg} \cdot \mathrm{g}^{-1}$ for $\mathrm{Ni}$ and $5.43 \mathrm{mg} \cdot \mathrm{g}^{-1}$ for $\mathrm{Cd}$. We considered that the maximum removal capacity was obtained the first time that the slope of the batch test between two consecutive points was smaller than 3\%. However, the removal capacity for Cu (Figure 2c), Zn (Figure $2 \mathrm{~d}$ ), and $\mathrm{Pb}$ (Figure 2e) did not show stabilization with an increase in the metal concentration, which means that the material did not reach its maximal removal limit. In contrast, Arlita presented a stabilization in its removal capacity for four out of the five elements considered: $\mathrm{Ni}, \mathrm{Zn}, \mathrm{Cd}$, and $\mathrm{Pb}$ at equilibrium concentrations of 84.61, 122.56, 33.47, and $170.70 \mathrm{mg} \cdot \mathrm{L}^{-1}$, and a retention capacity of $1.59,2.37,1.33$, and $10.13 \mathrm{mg} \cdot \mathrm{g}^{-1}$, respectively. Arlita's removal capacity for $\mathrm{Cu}$ increased with concentration and did not stabilize in the range of the tested concentrations. In the batch tests developed with solutions containing individual contaminants, the average removal capacities for Arlita and Filtralite were 76\% and $90 \%$, respectively, although the values varied across the different contaminants. For instance, removal capacities of Filtralite for $\mathrm{Cu}$ and $\mathrm{Pb}$ were higher than $97 \%$. Removal capacity for $\mathrm{Zn}$ was $94 \%$ and that for $\mathrm{Cd}$ was $88 \%$. These results are in agreement with other removal capacities achieved when contaminated waters containing heavy metals were treated with other materials such as vermiculite, kaolinite [64], bentonite, volcanic ash soil [65], or zeolites [66], among others. 

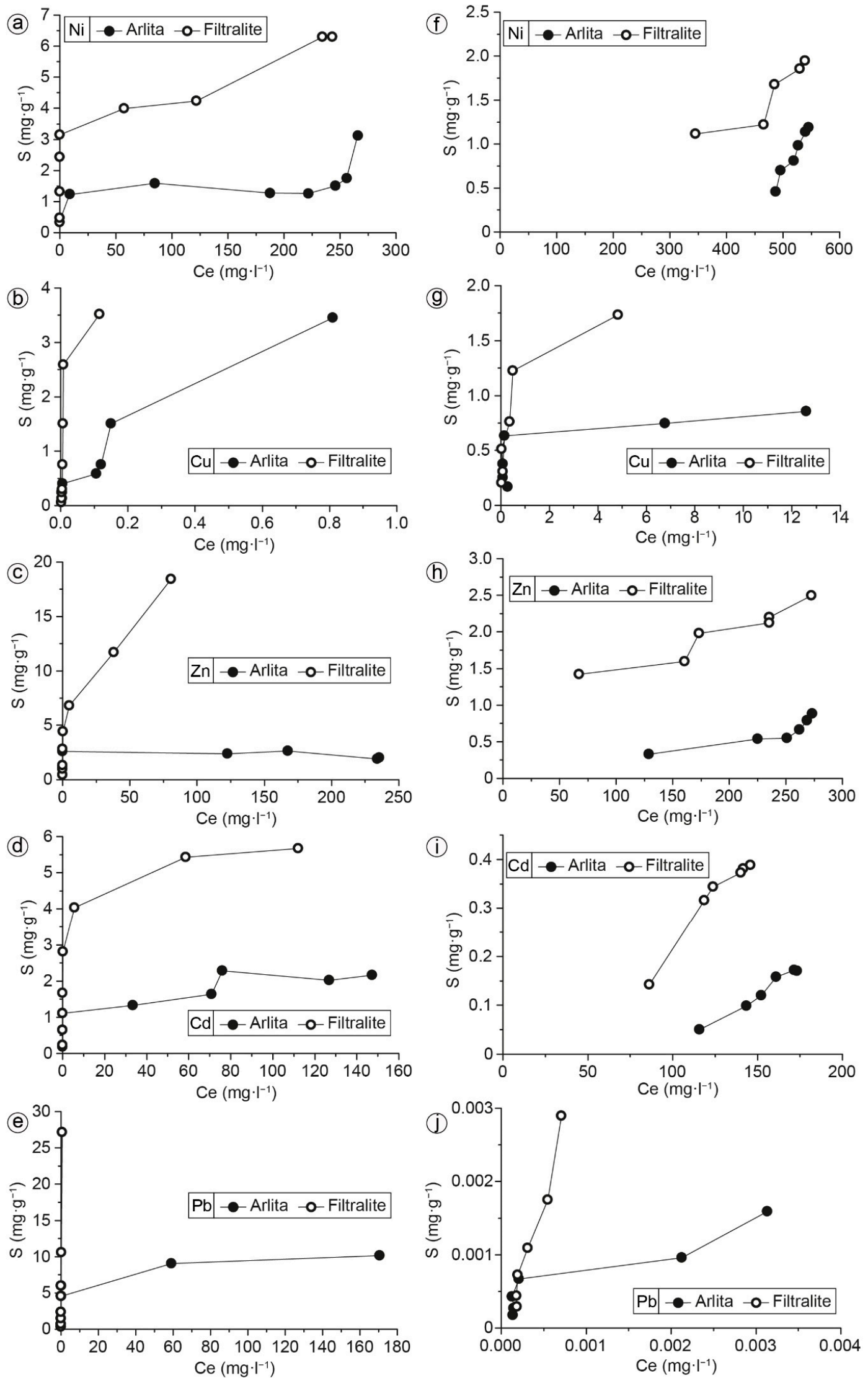

Figure 2. Adsorption isotherms of heavy metals for each contaminant obtained from solutions with individual contaminants (a-e) and from multielemental solutions $(\mathbf{f}-\mathbf{j})$. 
Results from multielemental solutions (Figure $2 \mathrm{f}-\mathrm{j}$ ) allow evaluating the synergistic or additive adsorption effects of the co-existing contaminants. The general trend described for both materials was the same that appeared when the contaminants were studied individually. Thus, Filtralite always had a higher removal capacity than Arlita in the studied multielemental contaminated solutions. Comparing batch tests with individual and multielemental solutions, the latter always presented higher values of equilibrium concentration and lower values of removal capacity than the individual solutions (Figure 2). The contaminant removal of LWA increased with concentration and did not reach the maximum. Consequently, removal efficiencies were lower than in batch tests for individual contaminants. The competition among all elements in the initial solution to be removed by the LWA resulted in a decrease in the final value of removed elements for all the heavy metals considered. Considering that real stormwaters may contain many types of pollutants such as hydrocarbons, suspended solids, organic matter, etc. [16,19-23], the removal efficiencies of the studied materials for heavy metals might have been affected by the presence of other pollutants [67].

With the multielemental solutions, the elimination of Ni by Arlita decreased from more than 6 to less than $2 \mathrm{mg} \cdot \mathrm{g}^{-1}$. Cu concentration decreased from 18 to $2.5 \mathrm{mg} \cdot \mathrm{g}^{-1}$, and this decrease was from more than 25 to $0.003 \mathrm{mg} \cdot \mathrm{g}^{-1}$ in the case of $\mathrm{Pb}$. These results showed that, in the case of contamination with a combination of all elements, the removal efficiency for $\mathrm{Pb}$ was much more affected than others such as $\mathrm{Cu}$ or $\mathrm{Ni}$.

Results from the test that evaluated the reversibility process are collected graphically in Figure 3. The maximum concentrations of contaminants in experiments developed with contaminated particles and deionized water were $0.055 \mathrm{mg} \cdot \mathrm{L}^{-1}$ and $0.05 \mathrm{mg} \cdot \mathrm{L}^{-1}$ for bottles containing Arlita contaminated with $\mathrm{Cd}$ and $\mathrm{Zn}$ solutions, respectively (Figure 3a). Equilibrium concentrations when employing Filtralite were always lower than when using Arlita, independently of the aqueous initial solution, revealing that Filtrate is not only better for metal removal but also for fixing the contaminants, thereby not releasing them back to the water.
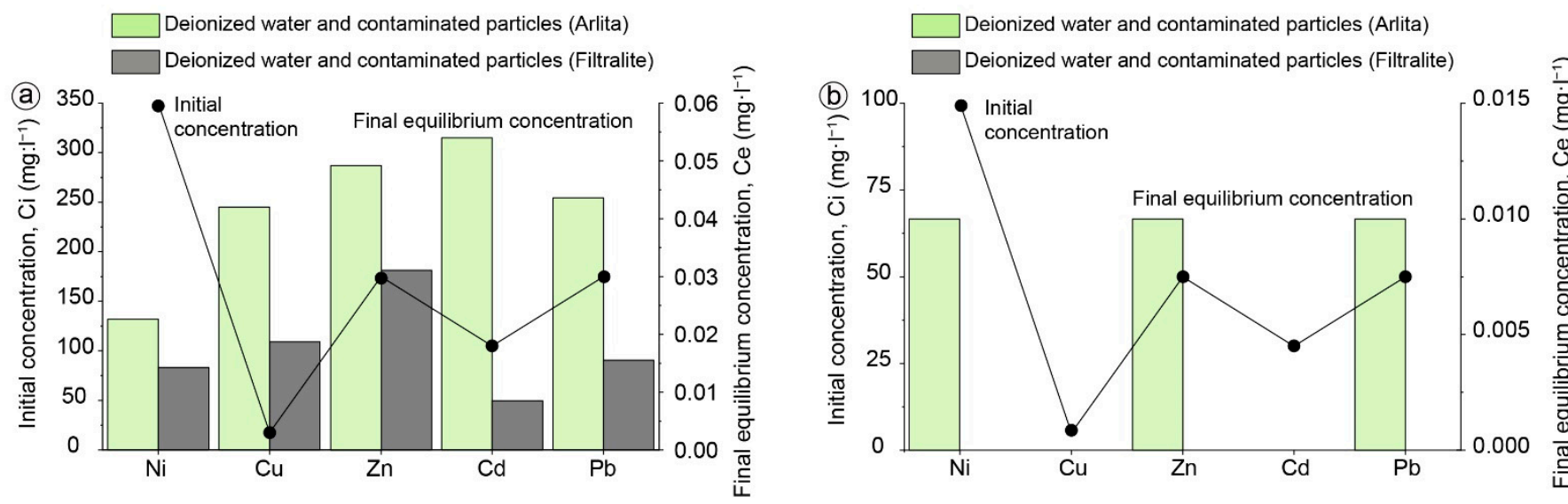

Figure 3. Final equilibrium concentration (Ce) in batch tests developed with deionized water and contaminated particles from previous batch tests performed with individual contaminated solutions (a) and multielemental solutions (b) employing the indicated initial concentration (Ci) for the different contaminants.

When studying the case of the multielemental solution, the equilibrium concentration in the end of the batch test confirmed that both LWAs mostly removed and stabilized the contaminants, and only a minimum fraction returned to the solution when the contaminated material mixed with clean water. The equilibrium concentration for all the contaminants was nearly $0 \mathrm{mg} \cdot \mathrm{L}^{-1}$ for all metals in the case of Filtralite. In the case of Arlita, slightly higher equilibrium concentrations were detected for $\mathrm{Ni}, \mathrm{Zn}$, and $\mathrm{Pb}$; nevertheless, the equilibrium concentration remained very low and should be considered below the error range of equipment. This concentration fraction could be related to the 
sorbed cations on the LWA surface, which were relatively mobile via ion-exchange reactions. These results corroborated that chemical precipitation (preferable to ion-exchange reactions) removed most of the contaminants, which remained stable (insoluble) in alkaline conditions. Other potential processes associated with adsorption and/or complexation to organic matter should not be disregarded in natural soils where organic matter content may be important. Real-scale processes imply the consideration of the rainfall regime in the study of the efficiency of these materials. Dry periods between two consecutive rain events, especially in semiarid environments, biofilm formation onto filter materials when suitable moist conditions appear, and/or the lifetime of the filter materials [56] are among the factors that should be considered in future steps.

\subsection{Influence of $\mathrm{pH}$ on Heavy-Metal Removal}

The $\mathrm{pH}$ values of the different contaminated initial solutions employed in the batch tests ranged from 4.2 to 6.4 (Figure 4). The tests developed with multielemental solutions presented the lowest initial $\mathrm{pH}$ values in comparison to the individual contaminated solutions. The $\mathrm{pH}$ values in water after the batch experiments were always higher than $\mathrm{pH}$ values in the initial water for all individually contaminated and multielemental solutions, and the increase was always higher for Filtralite than for Arlita.

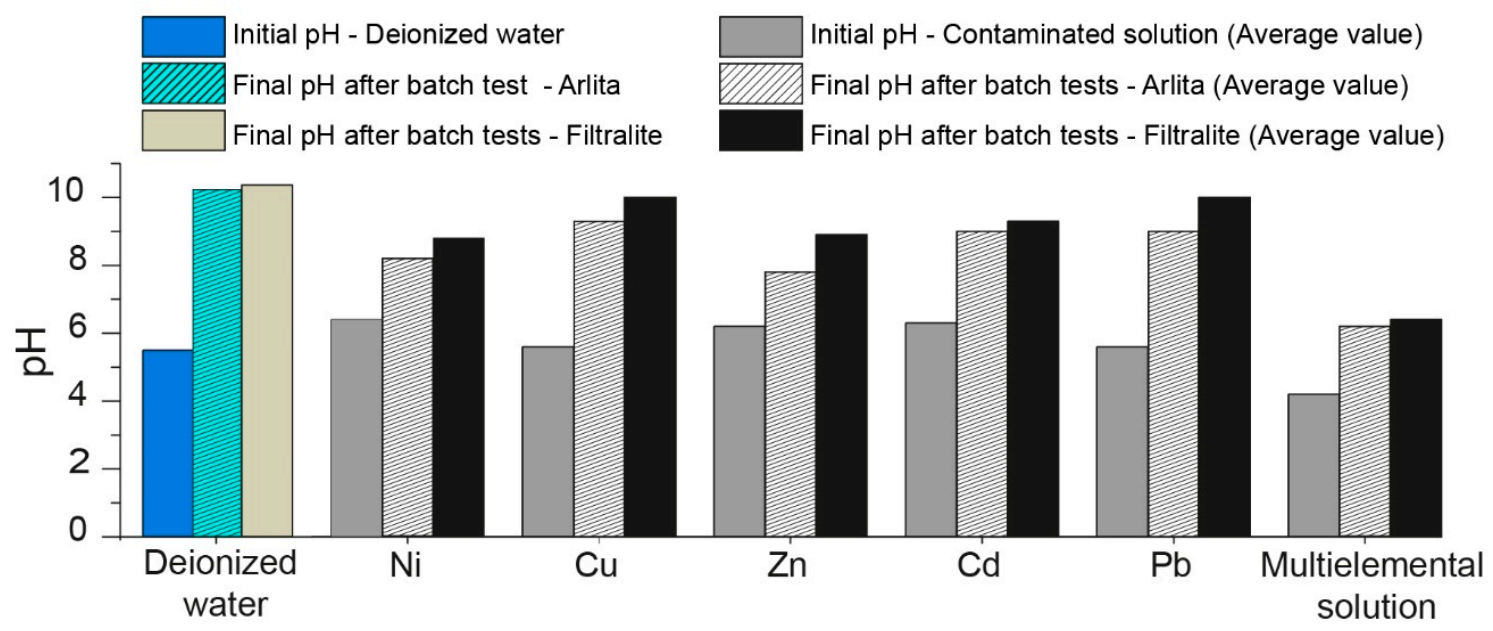

Figure 4. Initial and final average $\mathrm{pH}$ values for deionized water and contaminated solutions (individual or multiple contaminants) employed in the batch tests.

Results from the latest batch test which used deionized water (designed exclusively to study the influence of Arlita and Filtralite on the solution $\mathrm{pH}$ ) confirmed the tendency and showed a remarkable $\mathrm{pH}$ rise, from less than 6 to more than 10, which was higher than that achieved with any other contaminated solution.

The increase in $\mathrm{pH}$ as a consequence of the interaction with LWAs strongly affected the heavy-metal removal. The batch tests with whatever contaminant presented reductions in concentration (Figure 2) and increases in $\mathrm{pH}$ (Figure 4).

Consequently, results from batch tests not only evaluated the pure adsorption process of the studied materials but also included the decrease in heavy-metal concentration because of the metal precipitation due to rises in $\mathrm{pH}$.

The mineralogical characterization revealed that the presence of soluble and basic minerals (such as calcite or dolomite) was negligible (Table 1). On the contrary, a rise in $\mathrm{pH}$ always occurred simultaneously to an increase in $\mathrm{Mg}, \mathrm{K}$, and $\mathrm{Ca}$ in the final solution. Figure 5 shows the concentration of $\mathrm{Mg}, \mathrm{K}$, and $\mathrm{Ca}$ in the contaminated solutions in the equilibrium, after the stirring process. Ca concentration in the equilibrium solution with Arlita (Figure 5a) was substantial with values up to $70 \mathrm{mg} \cdot \mathrm{L}^{-1}$ for batch experiments with the $\mathrm{Zn}$-contaminated solution. Average values for $\mathrm{Mg}$, $\mathrm{K}$, and $\mathrm{Ca}$ concentration 
in contaminated solutions were $15.9,6.1$, and $47.6 \mathrm{mg} \cdot \mathrm{L}^{-1}$ for Arlita and $44.5,8.2$, and $22.6 \mathrm{mg} \cdot \mathrm{L}^{-1}$ for Filtralite, respectively (Figure $5 \mathrm{~b}$ ).
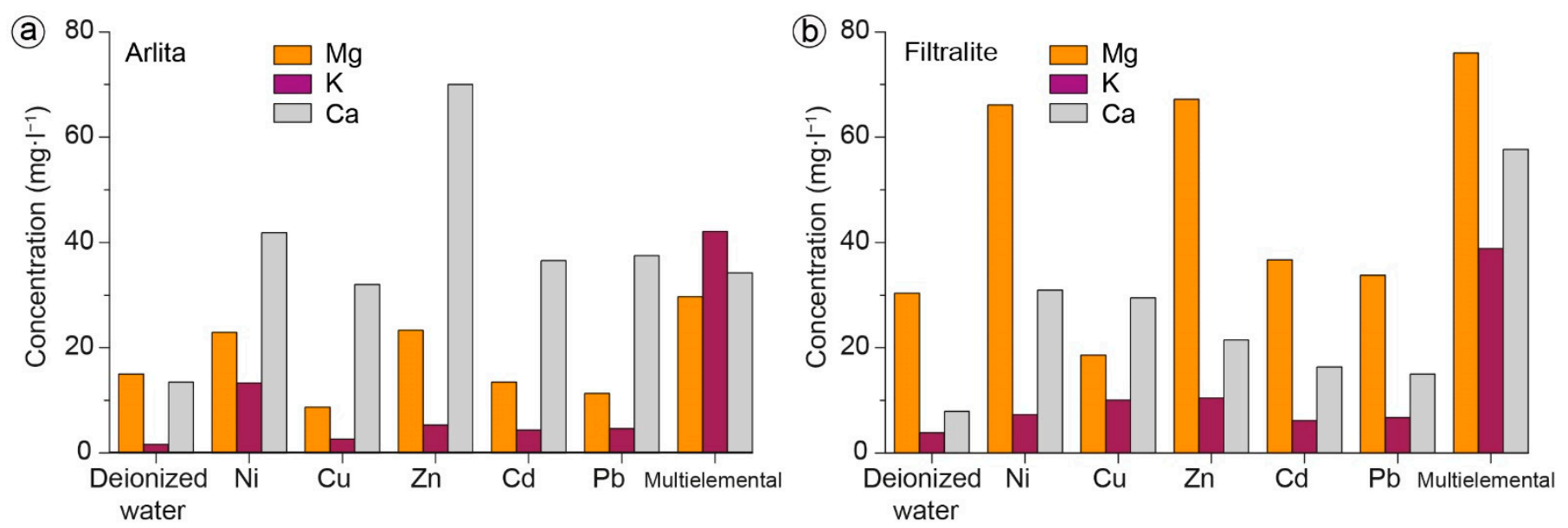

Figure 5. Final concentration equilibrium (Ce) for $\mathrm{Mg}$, $\mathrm{K}$, and $\mathrm{Ca}$ in the batch tests with deionized water and contaminated solutions (individual and multiple contaminants) employing Arlita (a) and Filtralite (b). The figure shows average results from five batch tests performed with $10 \mathrm{~g}$ of material and concentrations ranging from 50 to $500 \mathrm{mg} \cdot \mathrm{L}^{-1}$ (Ni), 2.5 to $25 \mathrm{mg} \cdot \mathrm{L}^{-1}(\mathrm{Cu}), 25$ to $250 \mathrm{mg} \cdot \mathrm{L}^{-1}(\mathrm{Zn}), 15$ to $150 \mathrm{mg} \cdot \mathrm{L}^{-1}(\mathrm{Cd})$, and 5 to $50 \mathrm{mg} \cdot \mathrm{L}^{-1}(\mathrm{~Pb})$.

Similar results were also found in the case of the additional batch tests that employed the contaminated particles and deionized water (Figure 6). $\mathrm{Mg}$, $\mathrm{K}$, and Ca showed a similar trend, with final concentrations of 20.5, 2.4, and $12.2 \mathrm{mg} \cdot \mathrm{L}^{-1}$ for Arlita (Figure 6a) and 23.7, 3.2 , and $5.8 \mathrm{mg} \cdot \mathrm{L}^{-1}$ for Filtralite, respectively (Figure $6 \mathrm{~b}$ ).
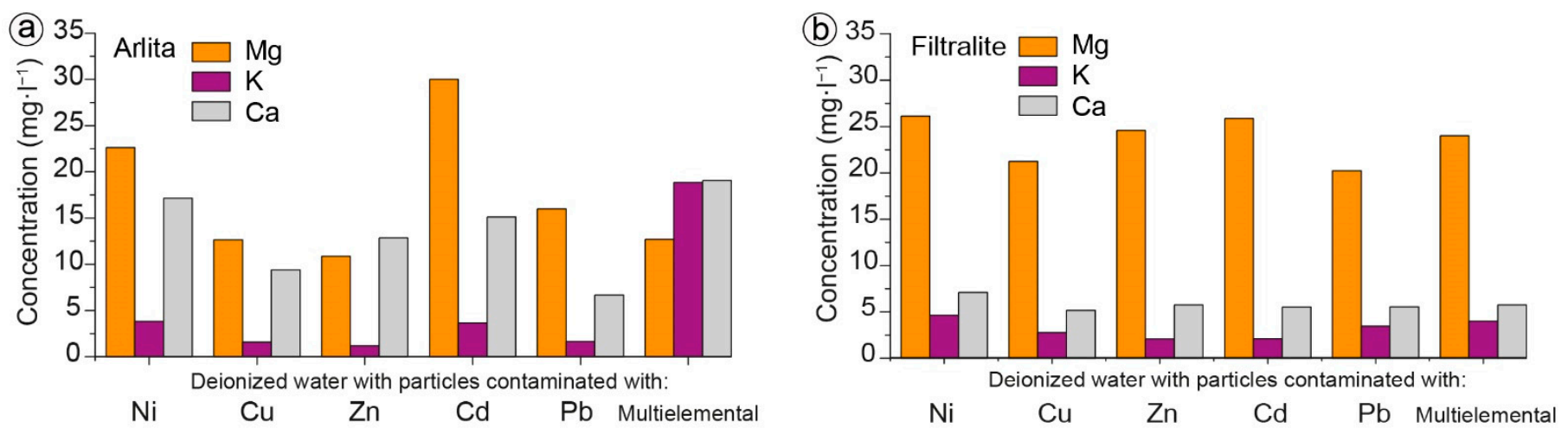

Figure 6. Final concentration equilibrium (Ce) for $\mathrm{Mg}, \mathrm{K}$, and $\mathrm{Ca}$ in the batch tests with deionized water and $5 \mathrm{~g}$ of contaminated particles from previous batch tests with contaminated solutions (individual and multiple contaminants) employing Arlita (a) and Filtralite (b).

The interaction of LWAs with water led to $\mathrm{pH}$ increases (drop in the $\mathrm{H}^{+}$concentration) and major elements released from the solid surface (Figures 5 and 6). These chemical variations suggest that the sorbing surface sites of the forming minerals of Arlita and Filtralite may interchange with $\mathrm{H}^{+}$, as well as heavy-metal species. Thus, they were exchanged with $\mathrm{Ca}$ on anortite, $\mathrm{K}$ on $\mathrm{K}$-feldspar, and $\mathrm{Mg}$ on wadsleyite. Consequently, the final solutions at equilibrium presented higher $\mathrm{pH}$ as $\mathrm{H}^{+}$reacted at the sorbing surface sites.

Heavy-metal species underwent ion-exchange reactions with these silicates, as well as with the amorphous iron oxides, which were detected with XRD and Raman analyses. In basic conditions, these amorphous iron phases presented a negative surface charge [68] and contributed to ion-exchange reactions on the surface of LWAs. Consequently, these 
superficial reactions decreased the concentration of the heavy metals in the contaminated solution and highlighted the removal capabilities of Arlita and Filtralite via adsorption.

The $\mathrm{pH}$ influenced the heavy-metal removal by LWAs not only via the sorption reactions but also via oxide precipitation as a consequence of the $\mathrm{pH}$ increase. A final test was developed to evaluate the chemical precipitation mechanism and the effect of the precipitation in the contaminated solution; the $\mathrm{pH}$ of the multielemental solution (without the presence of LWA) was increased by adding $\mathrm{NaOH}$ (from 4.2 to 11.3), and it was later decreased by adding $\mathrm{HCl}$ (from 11.3 to 3.4). Solution samples were collected at each $\mathrm{pH}$ stage, and contaminant concentrations were evaluated (Figure 7). Results showed that the final concentration of contaminants directly depended on $\mathrm{pH}$ values, reaching the lowest concentrations with the highest $\mathrm{pH}$. At the maximum $\mathrm{pH}$ (11.3), the concentration of contaminants in the aqueous solution was nearly 0 . When the process was reversed and $\mathrm{pH}$ decreased from 11.3 to 3.4 , the concentration of contaminants in the aqueous solution increased to nearly the initial concentration, which highlights the importance of the solution $\mathrm{pH}$ for heavy-metal removal. Within the $\mathrm{pH}$ range of stormwater, between 6 and 7 [62], the concentration of heavy metals achieved the maximum value for all the studied components (116.1 mg. $\mathrm{L}^{-1}$ for $\mathrm{Ni}, 8.2 \mathrm{mg} \cdot \mathrm{L}^{-1}$ for $\mathrm{Cu}, 58.1 \mathrm{mg} \cdot \mathrm{L}^{-1}$ for $\mathrm{Zn}, 29.7 \mathrm{mg} \cdot \mathrm{L}^{-1}$ for $\mathrm{Cd}$, and $8.8 \mathrm{mg} \cdot \mathrm{L}^{-1}$ for $\mathrm{Pb}$; Figure 7).

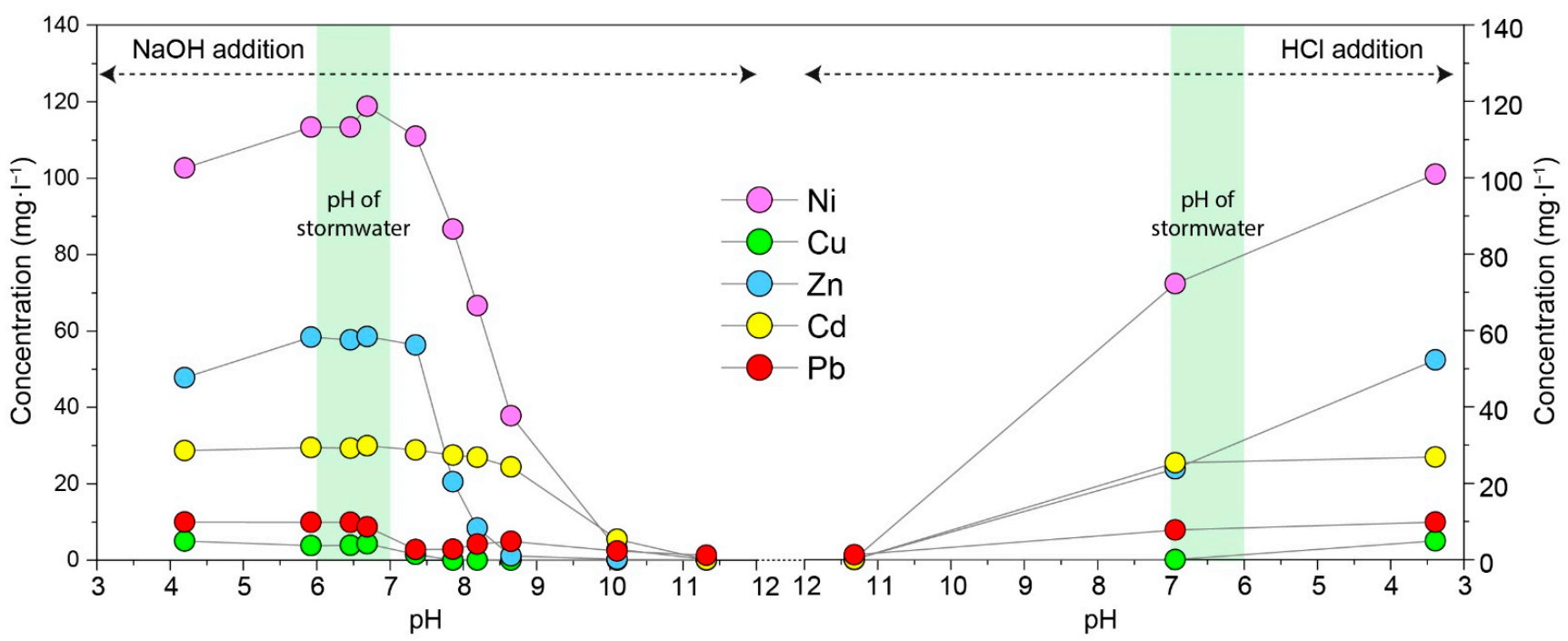

Figure 7. Changes in concentration of contaminants in the most concentrated multielemental solution due to $\mathrm{pH}$ variations. The $\mathrm{pH}$ range of stormwater is marked in the figure.

\subsection{Geochemical Modeling}

The presence of precipitates on the LWA surface was analyzed under FESEM after the batch test performed with the most concentrated individual and multielemental solutions (Figure 8). FESEM images revealed the presence of precipitated phases of the contaminants covering Arlita (Figure 8a-e) and Filtralite particles (Figure 8f). Precipitates presented nonequilibrium and amorphous forms as a consequence of a fast nucleation and precipitation. The distribution map of the precipitates obtained after the use of the multielemental solutions also suggested the precipitation and coprecipitation of heavy metals (Figure 8g-j). 

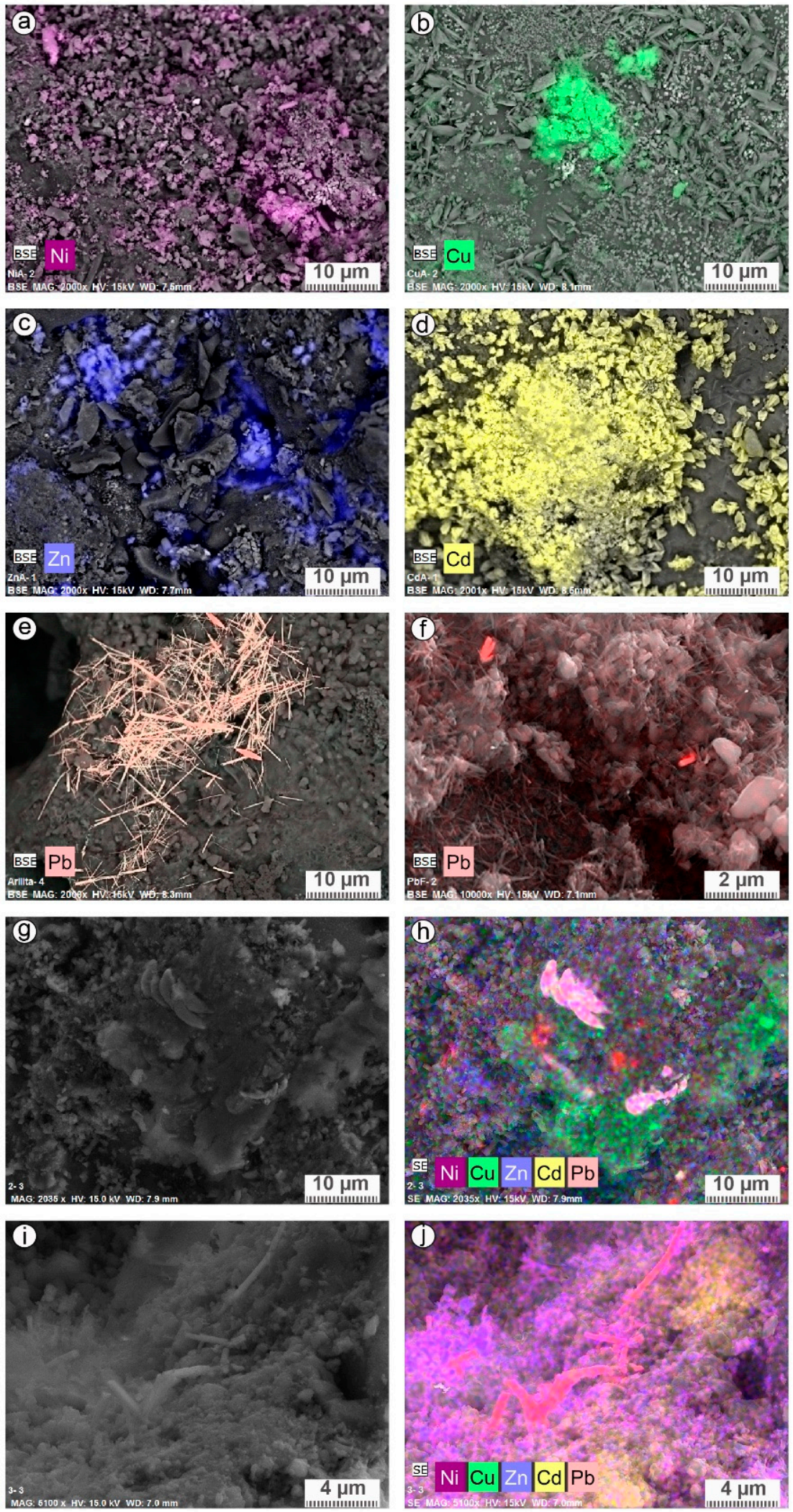

Figure 8. Field-emission scanning electron microscopy (FESEM) images and distribution map (mapping) of the different studied elements after batch experiments with the most concentrated solutions. Images show the forming precipitates on the particles from the batch tests containing solutions with individual contaminants (Arlita: (a-e); Filtralite: (f)) and with multielemental solutions (Arlita: (g,h); Filtralite: $(\mathbf{i}, \mathbf{j})$ ). 
The mineralogical composition of the precipitated phases on the LWA surfaces was not determined because they were undetected under XRD. In the experiments, the presence of $\mathrm{CO}_{3}{ }^{2-}$ in the solutions was scarce (only from the atmospheric $\mathrm{CO}_{2}$ ); thus, the presence of oxides and/or hydroxides of heavy metals was expected. In particular, $\mathrm{Pb}$ precipitated as lead sulfate in the multielemental solutions due to the presence of $\mathrm{SO}_{4}$ coming from the use of $\mathrm{ZnSO}_{4}, \mathrm{CuSO}_{4}$, and $\mathrm{CdSO}_{4}$ salts in their preparation.

Alternatively, heavy-metal removal via chemical precipitation was simulated with the PHREEQC code as $\mathrm{pH}$ increased. In basic conditions, insoluble phases such as carbonates, oxides, and/or hydroxides of heavy metals precipitated and coprecipitated, consequently being removed from the contaminated solutions [68]. The geochemical modeling with PHREEQC calculated the saturation index of selected metal oxides and hydroxides that could potentially precipitate on the LWA surface as $\mathrm{pH}$ increased (Figure 8). In these calculations, we used the most concentrated aqueous contaminated solutions, and we calculated the saturation index of the following minerals, while crystalline and amorphous (am) metal oxides and hydroxides were also included: for cadmium, Monteponite-CdO, $\mathrm{Cd}(\mathrm{OH})_{2}$, and $\mathrm{Cd}(\mathrm{OH})_{2}(\mathrm{am})$; for copper, Cuprite- $\mathrm{Cu}_{2} \mathrm{O}$, Tenorite- $\mathrm{CuO}$, and $\mathrm{Cu}(\mathrm{OH})_{2}$; for nickel, Bunsenite- $\mathrm{NiO}$ and $\mathrm{Ni}(\mathrm{OH})_{2}$; for zinc, Zincite- $\mathrm{ZnO}, \mathrm{Zn}(\mathrm{OH})_{2}$, and $\mathrm{Zn}(\mathrm{OH})_{2}(\mathrm{am})$; for lead, Litharge- $\mathrm{PbO}$ and $\mathrm{Pb}(\mathrm{OH})_{2}$. For the multielemental solution, $\mathrm{Pb}$ removal via precipitation of the insoluble $\mathrm{PbSO}_{4}$ was corrected by using the resulting water after anglesite $\left(\mathrm{PbSO}_{4}\right)$ precipitation.

Results showed that all phases were unsaturated before the batch tests (acidic $\mathrm{pHs}$ ) and became supersatured as $\mathrm{pH}$ increased after the interaction with LWAs (Figure 9). Because of a sufficiently high supersaturation of the solution, the amorphous phases suffered from rapid nucleation that potentially formed nonequilibrium with low crystallinity and/or amorphous phases. Moreover, according to the Gay-Lussac-Ostwald or Ostwald step rule [68], the nucleation of the amorphous phases (most soluble phases) was kinetically favored over less soluble analogues because of the lower interfacial energy (and, thus, lower nucleation energy) between minerals and solution. This fast precipitation could explain the nonequilibrium and amorphous forms that presented the precipitates.

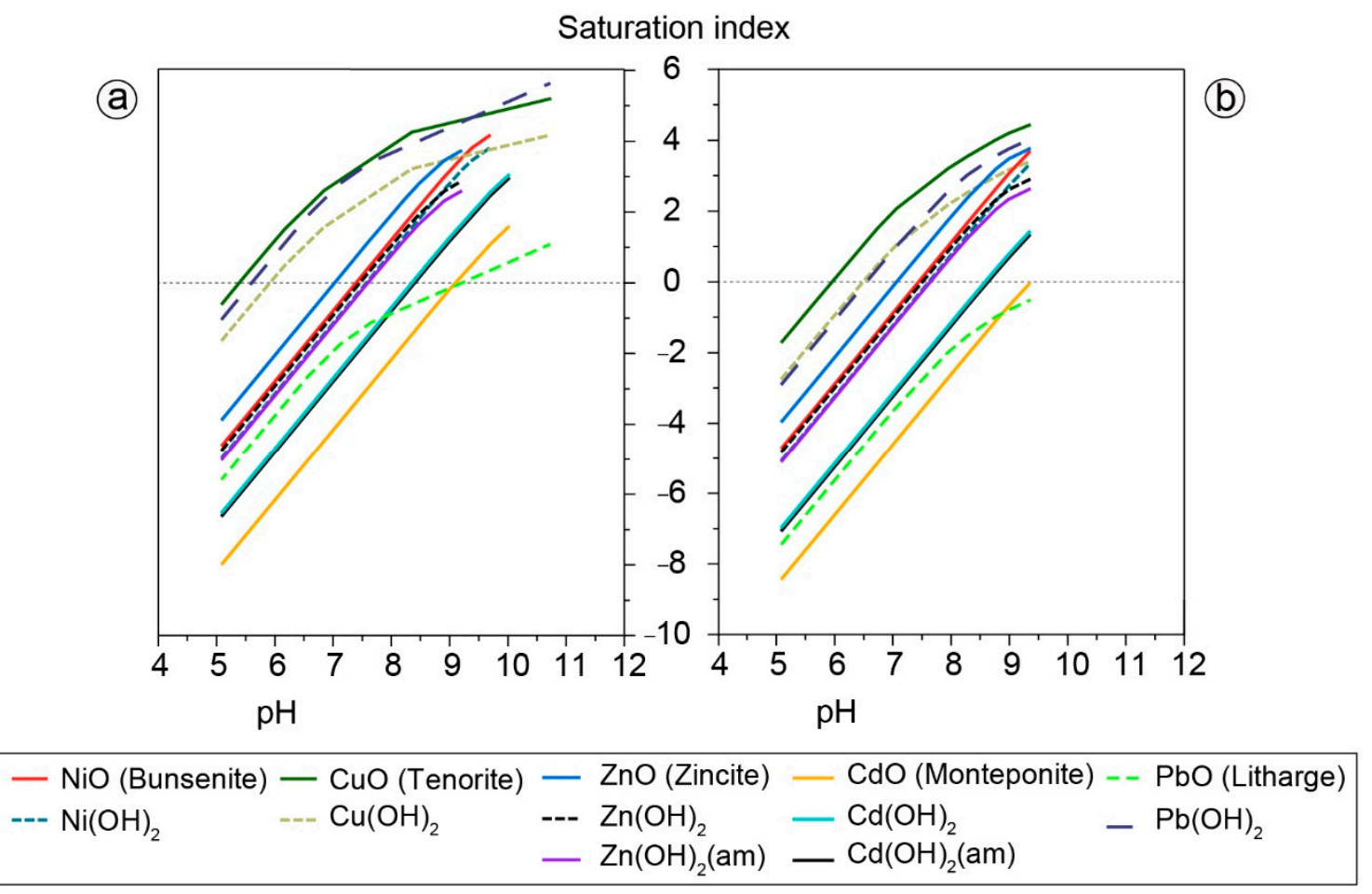

Figure 9. Variation of the saturation index of metal oxides and hydroxides with $\mathrm{pH}$ in the most concentrated solutions in batch tests: (a) individual contaminated solutions; (b) multielemental solutions. 
As previously mentioned, the removal efficiencies in the batch tests with multielemental solutions were lower than in the batch tests developed with individual contaminated solutions. The differences in the removal efficiencies can be explained by the higher supersaturation values that the precipitates reached in the solutions with individual contaminants (Figure 9a) in comparison to the multielemental solutions (Figure 9b).

This work demonstrates that Arlita and Filtralite present promising properties for removing heavy metals from urban stormwaters. The lifetime of both materials and the irreversibility of the decontamination process of Arlita and Filtalite [56] may ensure high removal capacities over time. However, deeper research may be developed to clearly establish the longevity of the LWA in relation to the cleaning or replacement of the material, as well as the occurrence of leakage of matter from the particles of Arlita and Filtralite if these materials were to be integrated within existing SUDS to improve the treatment of urban stormwater.

\section{Conclusions}

The presence of heavy metals in urban stormwaters constitutes a potential risk for water resources and aquatic life. Results from the present study showed the effectiveness of two different lightweight aggregates, Arlita and Filtralite, to remove heavy metals (Ni, $\mathrm{Cu}, \mathrm{Zn}, \mathrm{Cd}$, and $\mathrm{Pb}$ ) existent in aqueous solutions. The heavy-metal removal in LWAs can be attributed to two different mechanisms: first, the rough surface of LWA presents sorbing surface sites of the forming minerals, resulting in the ion-exchange reactions of metal ions; second, the increase in the aqueous solution $\mathrm{pH}$ via the LWA-water interaction causes the precipitation and coprecipitation of the metals as metal oxides and hydroxides.

The removal efficiencies in the batch tests developed with multielemental solutions were lower than in the batch tests performed with individual contaminated solutions, and the final concentration of heavy metals in the solid phase was considerably higher in the second case (individual solutions).

The analysis of the adsorption curves, the precipitates, and the geochemical mechanims revealed that, in alkaline conditions, a small quantity of metal is likely retained via ion exchange with the LWAs, forming minerals and iron amorphous phases. As a result, the high level of metal removal is possibly due to the formation of metal hydroxide or metal oxide precipitates.

Filtralite showed a better metal removal effeciency in all tests developed in the present study compared to Arlita. Filtralite interaction with contaminated solution led to a higher $\mathrm{pH}$, accelerating the precipitation mechanism. Moreover, the cleaning test with deionized water highlighted that Filtralite fixed heavy metals more efficiently than Arlita.

The use of Arlita and especially Filtralite presents exceptional properties for removing heavy metals from urban stormwaters. Further studies are required to study the performance of these LWAs when considering their practical application in sustainable urban drainage systems.

Author Contributions: Conceptualization, D.B. and J.V.-A.; funding acquisition, C.P. and D.B.; investigation, J.V.-A. and A.J.-A.; methodology, C.P., D.B., and J.V.-A.; project administration, C.P.; visualization, A.J.-A.; writing — original draft, C.P.; writing—review and editing, D.B. and J.V.-A. All authors have read and agreed to the published version of the manuscript.

Funding: This research was funded by the University of Alicante under the project GRE17-12, Generalitat Valenciana under the project GV/2020/059 and the Spanish Government under the project RTI2018-099052-B-I00.

Data Availability Statement: All the data presented in this study are publicly available in the repository of the University of Alicante (RUA) via http://hdl.handle.net/10045/109960 (accessed on 12 March 2021).

Acknowledgments: The authors acknowledge the Technical Research Services of the University of Alicante (SSTTI-UA) for the analyses performed using the equipment held at this institution, financed 
by the EU, MINECO, and Generalitat Valenciana (State Program for Knowledge Generation and Scientific and Technological Strengthening of the R+D+i System and P.O. FEDER 2007-2013 funds).

Conflicts of Interest: The authors declare no conflict of interest.

\section{References}

1. Kharin, V.V.; Zwiers, F.W.; Zhang, X.; Wehner, M. Changes in temperature and precipitation extremes in the CMIP5 ensemble. Clim. Chang. 2013, 119, 345-357. [CrossRef]

2. Quinn, R.; Dussaillant, A. Predicting infiltration pollutant retention in bioretention sustainable drainage systems: Model development and validation. Hydrol. Res. 2014, 45, 855-867. [CrossRef]

3. Sounthararajah, D.P.; Loganathan, P.; Kandasamy, J.; Vigneswaran, S. Adsorptive removal of heavy metals from water using sodium titanate nanofibres loaded onto GAC in fixed-bed columns. J. Hazard. Mater. 2015, 287, 306-316. [CrossRef] [PubMed]

4. Spahr, S.; Teixidó, M.; Sedlak, D.L.; Luthy, R.G. Hydrophilic trace organic contaminants in urban stormwater: Occurrence, toxicological relevance, and the need to enhance green stormwater infrastructure. Environ. Sci. Water Res. Technol. 2020, 6, 15-44. [CrossRef]

5. Boulos, P.F. Smart water network modeling for sustainable and resilient infrastructure. Water Resour. Manag. 2017, 31, 3177-3188. [CrossRef]

6. Schmitt, N.; Wanko, A.; Laurent, J.; Bois, P.; Molle, P.; Mosé, R. Constructed wetlands treating stormwater from separate sewer networks in a residential Strasbourg urban catchment area: Micropollutant removal and fate. J. Environ. Chem. Eng. 2015, 3 , 2816-2824. [CrossRef]

7. Wang, J.; Zhao, Y.; Yang, L.; Tu, N.; Xi, G.; Fang, X. Removal of heavy metals from urban stormwater runoff using bioretention media mix. Water 2017, 9, 854. [CrossRef]

8. Kharin, V.; Zwiers, F.; Zhang, X.; Hegerl, G. Changes in temperature and precipitation extremes in the IPCC ensemble of global coupled model simulations. J. Climate 2007, 20, 1419-1444. [CrossRef]

9. O'Gorman, P.A. Sensitivity of tropical precipitation extremes to climate change. Nat. Geosci. 2012, 5, 697-700. [CrossRef]

10. IPCC. Climate Change 2013: The Physical Science Basis. Contribution of Working Group I to the Fifth Assessment Report of the Intergovernmental Panel on Climate Change; Stocker, T.F., Qin, D., Plattner, G.-K., Tignor, M., Allen, S.K., Boschung, J., Nauels, A., Xia, Y., Bex, V., Midgley, P.M., Eds.; Cambridge University Press: Cambridge, UK; New York, NY, USA, 2013; p. 1535. [CrossRef]

11. Dallman, S.; Spongberg, M. Expanding local water supplies: Assessing the impacts of stormwater infiltration on groundwater quality. Prof. Geogr. 2012, 64, 232-249. [CrossRef]

12. Bouwer, H. Artificial recharge of groundwater: Hydrogeology and engineering. Hydrogeol. J. 2002, 10, 121-142. [CrossRef]

13. Cipolla, S.S.; Maglionico, M.; Stojkov, I. Experimental infiltration tests on existing permeable pavement surfaces. Clean Soil Air Water 2016, 44, 89-95. [CrossRef]

14. Naeimi, G.; Safavi, H.R. Integrated stormwater and groundwater management in urban areas, a case study. Int. J. Civ. Eng. 2019, 17, 1281-1294. [CrossRef]

15. Jodar-Abellan, A.; Valdes-Abellan, J.; Pla, C.; Gomariz-Castillo, F. Impact of land use changes on flash flood prediction using a sub-daily SWAT model in five Mediterranean ungauged watersheds (SE Spain). Sci. Total Environ. 2019, 657, 1578-1591. [CrossRef]

16. You, Z.; Zhang, L.; Pan, S.-Y.; Chiang, P.-C.; Pei, S.; Zhang, S. Performance evaluation of modified bioretention systems with alkaline solid wastes for enhanced nutrient removal from stormwater runoff. Water Res. 2019, 161, 61-73. [CrossRef] [PubMed]

17. Feldman, A.; Foti, R.; Montalto, F. Green infrastructure implementation in urban parks for stormwater management. J. Sustain. Water Built. Environ. 2019, 5, 05019003. [CrossRef]

18. Miskewitz, R.; Uchrin, C. In-stream dissolved oxygen impacts and sediment oxygen demand resulting from combined sewer overflow discharges. J. Environ. Eng. 2013, 139, 1307-1313. [CrossRef]

19. Ekanayake, D.; Aryal, R.; Hasan Johir, M.A.; Loganathan, P.; Bush, C.; Kandasamy, J.; Vigneswaran, S. Interrelationship among the pollutants in stormwater in an urban catchment and first flush identification using UV spectroscopy. Chemosphere 2019, 233, 245-251. [CrossRef] [PubMed]

20. Aryal, R.; Vigneswaran, S.; Kandasamy, J.; Naidu, R. Urban stormwater quality and treatment. Korean J. Chem. Eng. 2010, 27, 1343-1359. [CrossRef]

21. Dierkes, C.; Lohmann, M.; Becker, M.; Raasch, U. Pollution retention of different permeable pavements with reservoir structure at high hydraulic loads. In Proceedings of the 10th International Conference on Urban Drainage, Copenhagen, Denmark, 21-26 August 2005.

22. Vu, C.T.; Wu, T. Engineered multifunctional sand for enhanced removal of stormwater runoff contaminants in fixed-bed column systems. Chemosphere 2019, 224, 852-861. [CrossRef]

23. Zhang, J.; Wang, X.; Zhu, Y.; Huang, Z.; Yu, Z.; Bai, Y.; Fan, G.; Wang, P.; Chen, H.; Su, Y.; et al. The influence of heavy metals in road dust on the surface runoff quality: Kinetic, isotherm, and sequential extraction investigations. Ecotox. Environ. Safe 2019, 176, 270-278. [CrossRef]

24. Taka, M.; Aalto, J.; Virkanen, J.; Luoto, M. The direct and indirect effects of watershed land use and soil type on stream water metal concentrations. Water Resour. Res. 2016, 52, 7711-7725. [CrossRef] 
25. Raveh-Rubin, S.; Edery, Y.; Dror, I.; Berkowitz, B. Nickel migration and retention dynamics in natural soil columns. Water Resour. Res. 2015, 51, 7702-7722. [CrossRef]

26. Davis, A.P.; Shokouhian, M.; Sharma, H.; Minami, C.; Winogradoff, D. Water quality improvement through bioretention: Lead, copper, and zinc removal. Water Environ. Res. 2003, 75, 73-82. [CrossRef] [PubMed]

27. Reddy, K.R.; Xie, T.; Dastgheibi, S. Removal of heavy metals from urban stormwater runoff using different filter materials. $J$. Environ. Chem. Eng. 2014, 2, 282-292. [CrossRef]

28. Ramesh kumar, K.; Anbazhagan, V. Analysis and assessment of heavy metals in soils around the industrial areas in Mettur, Tamilnadu, India. Environ. Monit. Assess. 2018, 190, 519. [CrossRef]

29. Maniquiz-Redillas, M.C.; Kim, L.H. Evaluation of the capability of low-impact development practices for the removal of heavy metal from urban stormwater runoff. Environ. Technol. 2016, 37, 2265-2272. [CrossRef]

30. Pitt, R.; Field, R.; Lalor, M.; Brown, M. Urban stormwater toxic pollutants: Assessment, sources, and treatability. Water Environ. Res. 1995, 67, 260-275. [CrossRef]

31. Haile, T.M.; Fuerhacker, M. Simultaneous adsorption of heavy metals from roadway stormwater runoff using different filter media in column studies. Water 2018, 10, 1160. [CrossRef]

32. McPherson, T.N.; Burian, S.J.; Stenstrom, M.K.; Turin, H.J.; Brown, M.J.; Suffet, I.H. Trace metal pollutant load in urban runoff from a southern california watershed. J. Environ. Eng. 2005, 131, 1073-1080. [CrossRef]

33. Abdullah, N.; Yusof, N.; Lau, W.J.; Jaafar, J.; Ismail, A.F. Recent trends of heavy metal removal from water/wastewater by membrane technologies. J. Ind. Eng. Chem. 2019, 76, 17-38. [CrossRef]

34. Barakat, M.A. New trends in removing heavy metals from industrial wastewater. Arab. J. Chem. 2011, 4, 361-377. [CrossRef]

35. Hua, M.; Zhang, S.; Pan, B.; Zhang, W.; Lv, L.; Zhang, Q. Heavy metal removal from water/wastewater by nanosized metal oxides: A review. J. Hazard. Mater. 2012, 211-212, 317-331. [CrossRef]

36. Fu, F.; Wang, Q. Removal of heavy metal ions from wastewaters: A review. J. Environ. Manage. 2011, 92, 407-418. [CrossRef] [PubMed]

37. Carolin, C.F.; Kumar, P.S.; Saravanan, A.; Joshiba, G.J.; Naushad, M. Efficient techniques for the removal of toxic heavy metals from aquatic environment: A review. J. Environ. Chem. Eng. 2017, 5, 2782-2799. [CrossRef]

38. Alaba, P.A.; Oladoja, N.A.; Sani, Y.M.; Ayodele, O.B.; Mohammed, I.Y.; Olupinla, S.F.; Daud, W.M.W. Insight into wastewater decontamination using polymeric adsorbents. J. Environ. Chem. Eng. 2018, 6, 1651-1672. [CrossRef]

39. Fletcher, T.D.; Shuster, W.; Hunt, W.F.; Ashley, R.; Butler, D.; Arthur, S.; Trowsdale, S.; Barraud, S.; Semadeni-Davies, A.; BertrandKrajewski, J.-L.; et al. SUDS, LID, BMPs, WSUD and more-The evolution and application of terminology surrounding urban drainage. Urban Water J. 2015, 12, 525-542. [CrossRef]

40. Bockhorn, B.; Klint, K.E.S.; Locatelli, L.; Park, Y.-J.; Binning, P.J.; Sudicky, E.; Bergen Jensen, M. Factors affecting the hydraulic performance of infiltration based SUDS in clay. Urban Water J. 2017, 14, 125-133. [CrossRef]

41. Woods-Ballard, B.; Wilson, S.; Udale-Clarke, H.; Illman, S.; Scott, T.; Ashley, R.; Kellager, R. The SuDS manual; CIRIA: London, UK, 2015; p. 937.

42. Soleimanifar, H.; Deng, Y.; Wu, L.; Sarkar, D. Water treatment residual (WTR)-coated wood mulch for alleviation of toxic metals and phosphorus from polluted urban stormwater runoff. Chemosphere 2016, 154, 289-292. [CrossRef]

43. Charlesworth, S.M.; Nnadi, E.; Oyelola, O.; Bennett, J.; Warwick, F.; Jackson, R.; Lawson, D. Laboratory based experiments to assess the use of green and food based compost to improve water quality in a Sustainable Drainage (SUDS) device such as a swale. Sci. Total Environ. 2012, 424, 337-343. [CrossRef] [PubMed]

44. Öövel, M.; Tooming, A.; Mauring, T.; Mander, Ü. Schoolhouse wastewater purification in a LWA-filled hybrid constructed wetland in Estonia. Ecol. Eng. 2007, 29, 17-26. [CrossRef]

45. Albuquerque, C.M.; Labrincha, J.A. Removal of contaminants from aqueous solutions by beds made of rejects of the lightweight aggregates production. Ceram. Int. 2008, 34, 1735-1740. [CrossRef]

46. RD 506/2013, 2013. Real Decreto 506/2013, de 28 de Junio, Sobre Productos Fertilizantes. Available online: https:/ /www.boe.es / boe/dias/2013/07/10/pdfs/BOE-A-2013-7540.pdf (accessed on 12 March 2021).

47. RD 865/2010, 2010. Real Decreto 865/2010, de 2 de Julio, Sobre Sustratos de Cultivo. Available online: https: / /www.boe.es / buscar/pdf/2010/BOE-A-2010-11153-consolidado.pdf (accessed on 12 March 2021).

48. RD 1310/1990, 1990. Real Decreto 1310/1990, de 29 de Octubre, por el que se Regula la Utilización de los Lodos de Depuración en el Sector Agrario. Available online: https://www.boe.es/eli/es/rd/1990/10/29/1310/dof/spa/pdf (accessed on 12 March 2021).

49. UE 2015/2099, 2015. Decisión (UE) 2015/2099 de la Comisión, de 18 de Noviembre de 2015, por la que se Establecen los Criterios Ecológicos Para la Concesión de la Etiqueta Ecológica de la UE a Sustratos de Cultivo, Enmiendas del Suelo y Cubiertas del Suelo. Available online: https:/ / eur-lex.europa.eu/legal-content/ES/TXT/PDF/?uri=CELEX:32015D2099\&from=ES (accessed on 12 March 2021).

50. Davis, A.P.; Burns, M. Evaluation of lead concentration in runoff from painted structures. Water Res. 1999, 33, $2949-2958$. [CrossRef]

51. Davis, A.P.; Shokouhian, M.; Ni, S. Loading estimates of lead, copper, cadmium, and zinc in urban runoff from specific sources. Chemosphere 2001, 44, 997-1009. [CrossRef] 
52. Martin, J.D. Using XPowder: A software package for Powder X-Ray diffraction analysis. D.L. GR 1001/04, 2004. Available online: http:/ / www.xpowder.com/download/QuickUserGuideForXPowderX.pdf (accessed on 12 March 2021).

53. Rouquerol, J.; Avnir, D.; Fairbridge, C.; Everett, D.; Haynes, J.; Pernicone, N.; Ramsay, J.; Sing, K.; Unger, K. Recommendations for the characterization of porous solids (Technical Report). Pure Appl. Chem. 1994, 66, 1739-1758. [CrossRef]

54. Wang, Q.; Zhang, Q.H.; Dzakpasu, M.; Chang, N.N.; Wang, X.C. Transferral of HMs pollution from road-deposited sediments to stormwater runoff during transport processes. Front. Env. Sci. Eng. 2019, 13, 13. [CrossRef]

55. Reddy, K.R.; Kumar, G. Permeable reactive filter systems for the treatment of urban stormwater runoff with mixed pollutants. In Geotechnical Frontiers 2017: Waste Containment, Barriers, Remediation, and Sustainable Geoengineering; Brandon, T.L., Valentine, R.J., Eds.; American Society of Civil Engineers: Orlando, FL, USA, 2017; pp. 508-517.

56. Pla, C.; Benavente, D.; Valdes-Abellan, J.; Kovacova, Z. Effectiveness of two lightweight aggregates for the removal of heavy metals from contaminated urban stormwater. J. Contam. Hydrol. 2021, 239, 103778. [CrossRef] [PubMed]

57. UNE-ISO10390:2012. Soil Quality. Determination of pH. 2012. Available online: https://www.iso.org/standard/40879.html (accessed on 12 March 2021).

58. Parkhurst, D.L.; Appelo, C.A.J. Description of Input and Examples for PHREEQC, Version 3. A Computer Program for Speciation, Batch-Reaction, One-Dimensional Transport, and Inverse Geochemical Calculations; Techniques and Methods, Book 6; U.S. Geological Survey: Denver, CO, USA, 2013; Chapter A43; p. 497. Available online: https://pubs.usgs.gov/tm/06/a43/ (accessed on 12 March 2021).

59. Benavente, D.; Brimblecome, P.; Grossi, C. Thermodynamic calculations for the salt crystallisation damage in porous built heritage using PHREEQC. Environ. Earth Sci. 2015, 74, 2297-2313. [CrossRef]

60. Kerolli-Mustafa, M.; Bačić, I.; Ćurković, L. Investigation of jarosite process tailing waste by means of raman and infrared spectroscopy. Materialwiss. Werkst. 2013, 44, 768-773. [CrossRef]

61. Márquez, G.E.; Ribeiro, M.J.P.; Ventura, J.M.; Labrincha, J.A. Removal of nickel from aqueous solutions by clay-based beds. Ceram. Int. 2004, 30, 111-119. [CrossRef]

62. Sounthararajah, D.; Loganathan, P.; Kandasamy, J.; Vigneswaran, S. Removing heavy metals using permeable pavement system with a titanate nano-fibrous adsorbent column as a post treatment. Chemosphere 2017, 168, 467-473. [CrossRef]

63. Cuong, D.V.; Liu, N.-L.; Nguyen, V.A.; Hou, C.-H. Meso/micropore-controlled hierarchical porous carbon derived from activated biochar as a high-performance adsorbent for copper removal. Sci. Total Environ. 2019, 692, 844-853. [CrossRef]

64. Farsi, A.; Aghasi, M.; Esmaeili, A.; Eslami, H. Efficient removal of $\mathrm{Cu}(\mathrm{II})$ and $\mathrm{Zn}$ (II) from aqueous solution and real acid mine drainage by natural vermiculite and kaolinite. Desalin. Water Treat. 2020, 204, 224-237. [CrossRef]

65. Esmaeili, A.; Mobini, M.; Eslami, H. Removal of heavy metals from acid mine drainage by native natural clay minerals, batch and continuous studies. Appl. Water Sci. 2019, 9, 97. [CrossRef]

66. Irannajad, M.; Kamran Haghighi, H. Removal of heavy metals from polluted solutions by zeolitic adsorbents: A review. Environ. Process. 2021, 8, 7-35. [CrossRef]

67. Brink, I.; Kamish, W. Associations between stormwater retention pond parameters and pollutant (suspended solids and metals) removal efficiencies. Water SA 2018, 44, 45-53. [CrossRef]

68. Langmuir, D. Aqueous Environmental Geochemistry; Prentice Hall: Upper Saddle River, NJ, USA, 1997. 